\title{
An Exploration of the Readiness, Challenges and Expected Support for their Overseas Study of Chinese Business and Management Programme Students
}

\author{
Chengbo Wang, Edgehill University, chengbo.wang@edgehill.ac.uk \\ Xiaomei Li, Tianjin University \\ Xuan Ou, Hunan International Economics University \\ James O'Kane, Edge Hill University \\ Zhaofang Mao, Tianjin University \\ Wenquan Zhang, Yanbian University
}

\begin{abstract}
Chinese students are the largest international student cohort in the higher education institutions of English-speaking developed countries. The paper explores strategies to enhance the Chinese students' learning efficacy in overseas institutions. This research differs from other research focusing on international students already in English-speaking institutions; it explores the readiness of potential Chinese international students before departure from China, their anticipated challenges for study abroad and expected support from host institutions and staff. Besides the insights of anticipated challenges and expected support, the key findings include: the majority of the sample students are financially ready for overseas study, however they are not fully ready on English language; students from the public institute in the study have a higher level of readiness for subject knowledge than their private institute's peers. The findings offer a guide, to both the English-speaking institutions and their Chinese partners, on facilitating, teaching and preparing the Chinese students for a fruitful learning experience abroad and enhanced academic performance.
\end{abstract}

Key words: Higher education, China, overseas students, readiness, challenges, expectations, English-speaking developed countries

\section{Introduction}

Since the open-to-outside policy in China was launched at the end of 1970's, the number of Chinese graduates going abroad to further their higher education (hereafter referred to as Chinese international students) has been continuously increasing (EOL, 2013a; DOE, 2012); this made China the country providing the largest number of international students in the world to English speaking developed countries' (ESDCs') higher education institutions; the largest portion of these students study in business and management programmes (EOL, 2013a; Huashen-Edu, 2012; EOL, 2014).

Currently, within the United Kingdom (UK), more international students enrol in business and management-focused programmes than other programmes and the largest proportion of those are Chinese international students (HESA, 2012; HESA, 2007; UKCISA, 2012). Although the higher education institutions have committed to help the international students improve their learning efficiency and effectiveness in the new environment, compared to the international students coming from Western countries with similar education environment as the UK's (such 
as the USA, France), Chinese international students have met many difficulties; similar to the experiences of other Asian students. The authors conducted a small-scale interview of eight Chinese business and management students at postgraduate and undergraduate levels and found that the identified difficulties by researchers (Bamford, 2008; Sawir, 2005; Hellstén and Prescott, 2004; Wong, 2004) for Asian students have also been encountered by the Chinese students, including: communication, group work, critical thinking and analysis, learning styles' adjustment, cultural and social environment adaptation.

According to HUST (2010) and BFSU (2011), the graduates from business and management programmes are much demanded by employers, thus these programmes are among the education provisions appealing to potential students.

With the Chinese students as the largest overseas cohort in UK higher education institutions, developing a targeted teaching and learning strategy is sensible for ensuring an effective and efficient learning process and maintaining a good level of student progression and retention, which in turn would enhance the attractiveness of UK higher education institutions and other ESDC higher education institutions that offer a similar situation for potential Chinese students.

The aforementioned circumstances motivated the authors to carry out the research. This research, differs from other current research on international students as it explores the readiness of the potential Chinese international students (currently studying in Chinese higher education institutions) for study abroad and their anticipated challenges as well as expected support during their overseas study process. The research findings inform the curriculum and teaching strategy development of English-speaking higher education institutions; and consequentially provide the international students a fruitful learning process and enjoyable learning experience, which will contribute positively to the healthy survival and development of the host higher education institutions. The importance of such research has been further emphasised and evidenced by the Higher Education Academy funding call and the Teaching International Students initiative (HEA, 2013; HEA, 2010).

The paper is structured as following: the next section is literature review exploring the background to the research, followed by the methodology undertaken in the research, after which the empirical findings and analysis are presented, along with conclusions, implications, limitation and suggested future research.

\section{Literature review}

International cooperation and expansion of businesses are a current trend worldwide, which covers many aspects of a nation's society and economy, and the higher education sector is not an exception (Hou, et al., 2014; Luke, 2011; Marginson, 2006). Currently, not only are higher education institutions from developed countries internationalising their education provisions but institutions from some developing countries are also committed to such initiatives (TFSU, 2014; Peking University, 2014), with recruiting and educating international students as the key component. 


\section{Drivers for internationalisation of higher education}

There are four main drivers for internationalisation of higher education provision (Yemini, 2012; Bodycott and Lai, 2012; Qiang, 2003; Scott, 1998). First, in a global social and economic environment there is pressure on the professionals running businesses and organisations to develop the knowledge and skills that can be used to cope with the complexity of overseas situations with differences in cultural, economic, social and political dimensions. Second, the scale and scope of research requires extensive cooperation from researchers in different parts of the world. Third, the rapid development and application of information and communication technology and the ever-increasing acceptance and mastery from different countries' students of English as an international communication language. Fourth, and possibly the major driver, the improvement in the higher education institutions' financial situation (and the national economy) through the large number of overseas students paying tuition fees. Thus, from the higher education's supply side, there is a strong motivation for internationalisation of education provision.

Meanwhile, from the demand side of higher education, namely the potential international students and their parents, pursuing overseas higher education is also deemed as a beneficial investment for both the individual students and their families (Bodycott and Lai, 2012). This is because, besides international mindsets and language enhancement, the students can also secure a stronger profile in improving their employability (EOL, 2013a; DOE, 2012). The above phenomena have also been evidenced by the large number of UK higher education institutions (Complete University Guide, 2012) providing on-campus and off-shore international education programmes and the ever-growing international student cohorts at both undergraduate and postgraduate levels (HESA, 2012), as well as the overseas study intention expressed by potential international students (Huashen-Edu, 2012; EOL, 2014).

\section{Barriers for internationalisation of higher education}

Internationalisation is currently a salient trend in the education sector worldwide. Nevertheless, there are still barriers impeding its process. Among them, also as the focus of this research, are the difficulties faced by the international students in their studying at UK and other ESDCs' institutions, especially those Asian or Chinese students who had never been exposed to the teaching and learning styles in ESDC higher education systems (Bamford, 2008; Sawir, 2005; Hellstén and Prescott, 2004; Wong, 2004) before going abroad. The difficulties include: the competence and confidence of communicating with the tutors and peer native students, the ability of understanding thoroughly the lecture contents, the skills and competence in group work, critical thinking and analysis, the ability of quick adjustment to the host institutions' learning styles, the ability of adapting to different cultural and social environment (Montgomery, 2010; Hellstén and Prescott, 2004; Bamford, 2008; Sawir, 2005; Wong, 2004; EOL, 2013a,b; EOL, 2014; Huashen-Edu, 2012).

However, the incumbent understandings with regard to the difficulties facing international students especially Chinese international students were mainly obtained from the students who have already been studying in the UK and other ESDC higher education institutions. Further, the approaches developed in facilitating and enhancing Chinese international students' learning efficacy based on these understandings do not focus on the very beginning stage, namely before 
the Chinese international students depart to the host institutions while they are still studying in China. There is a lack of research on the readiness and anticipated challenges as well as expected support from this type of students.

\section{Key elements to the international students' abroad study}

In this research, corresponding to the aforementioned difficulties for Chinese international students, based on the previous research and a focus group experts' contention, the authors have identified the elements and used them as questionnaire content enquiring about the readiness, challenges and expected support for international students' study abroad; and the developed questionnaire questions have been further examined, enriched and validated by a Delphi test and another academic focus group (Table 1).

Table 1. Summary of the finally confirmed questionnaire content elements and their sources

\begin{tabular}{|c|c|c|c|}
\hline Content elements & \multicolumn{2}{|c|}{$\begin{array}{l}\text { Aspects of questions within } \\
\text { the research questionnaire }\end{array}$} & Sources (direct and/or inspiration from) \\
\hline \multicolumn{2}{|l|}{ Willingness for abroad study $*$} & \multirow{10}{*}{ 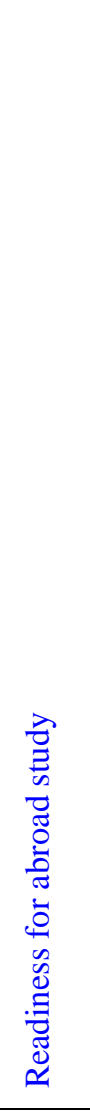 } & $\begin{array}{l}\text { Bodycott and Lai, 2012; EOL, 2013a,b; EOL, } \\
\text { 2014; Focus group experts }\end{array}$ \\
\hline \multicolumn{2}{|l|}{$\begin{array}{l}\text { The financial source for abroad } \\
\text { study* }\end{array}$} & & $\begin{array}{l}\text { Qide-Education (2013); Focus group experts; } \\
\text { Bodycott and Lai, } 2012\end{array}$ \\
\hline $\begin{array}{l}\text { Favouring level on English among } \\
\text { all the subjects * }\end{array}$ & \multirow{8}{*}{ 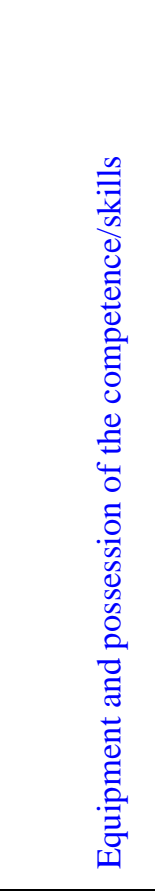 } & & $\begin{array}{l}\text { EOL, 2013a,b; Huashe-Edu, 2012; Delphi } \\
\text { panel/ focus group experts; Qide-Education } \\
\text { (2013); EOL, } 2014\end{array}$ \\
\hline $\begin{array}{l}\text { Academic performance on English } \\
\text { learning * }\end{array}$ & & & $\begin{array}{l}\text { Delphi panel/ focus group experts; } \\
\text { Qide-Education (2013); EOL, 2014; } \\
\text { Huashe-Edu, } 2012\end{array}$ \\
\hline \multirow{2}{*}{$\begin{array}{l}\text { The most difticult aspect in English } \\
\text { learning } \\
\text { The best way for learning English }\end{array}$} & & & Focus group experts \\
\hline & & & Focus group experts \\
\hline $\begin{array}{l}\text { The level of mastering subject } \\
\text { English words }\end{array}$ & & & Focus group experts \\
\hline $\begin{array}{l}\text { The level of subject knowledge } \\
\text { mastery }\end{array}$ & & & Focus group experts \\
\hline $\begin{array}{l}\text { English language tests having been } \\
\text { passed }\end{array}$ & & & Focus group experts \\
\hline $\begin{array}{l}\text { Reasons for joining the chosen } \\
\text { study programme }\end{array}$ & & & Focus group experts \\
\hline $\begin{array}{l}\text { The biggest barriers for overseas } \\
\text { study }\end{array}$ & \multirow{3}{*}{\multicolumn{2}{|c|}{$\begin{array}{l}\text { Challenges and expected } \\
\text { support }\end{array}$}} & $\begin{array}{l}\text { Sawir, 2005; Bamford, 2008; Hellstén and } \\
\text { Prescott, 2004; Wong, 2004; EOL, 2013a,b; } \\
\text { EOL, 2014; Huashe-Edu, } 2012\end{array}$ \\
\hline $\begin{array}{l}\text { The deemed advantage of the } \\
\text { teaching strategy of overseas } \\
\text { institutes }\end{array}$ & & & Focus group experts \\
\hline $\begin{array}{l}\text { The reasons for not willing to } \\
\text { express your viewpoints in the class }\end{array}$ & & & $\begin{array}{l}\text { Hellstén and Prescott, 2004; Bamford, 2008; } \\
\text { Sawir, 2005; Wong, 2004; EOL, 2013a,b; }\end{array}$ \\
\hline
\end{tabular}




\begin{tabular}{|c|c|}
\hline in overseas study & EOL, 2014; Huashe-Edu, 2012 \\
\hline $\begin{array}{l}\text { The anticipated biggest difficulties } \\
\text { at the beginning stage of overseas } \\
\text { study }\end{array}$ & $\begin{array}{l}\text { Focus group experts; Hellstén and Prescott, } \\
\text { 2004; Bamford, 2008; Sawir, 2005; Wong, } \\
\text { 2004; HEA, } 2010\end{array}$ \\
\hline $\begin{array}{l}\text { The most expected support/ } \\
\text { assistance from the staff in the } \\
\text { overseas institutes and the institutes } \\
\text { themselves }\end{array}$ & Focus group experts; HEA, 2010 \\
\hline
\end{tabular}

* Ordered categorical type data for in-depth statistic analysis

The questionnaire has been distributed to the potential international students in a top public and a top private Chinese institute, while they are still studying in China. Respondents from both public and private institutions were selected because research suggests differences in students' academic performance and characteristics in the two types of institution (Yu, 2011; Chen, 2011; Ye, 2008; Jin and Yin, 2009; Mao, 2008)

\section{Methods employed by the research}

\section{The general research strategy}

The primary data for this research are collected from two Chinese higher education institutions (one public and one private) using a survey as the research instrument. This research followed three stages to complete its process.

Stage 1, a literature review to obtain in-depth understanding of the issues focused by the research and, based on the identified elements from the review findings and further reflection, the authors and a focus group of five academic educators developed the questionnaire used by the research.

The questionnaire content for this paper focuses on the readiness of the potential Chinese international students, specifically: on the aspects of willingness to go abroad; the sources of finance; the skills or competence for fulfilling the overseas study tasks. It also explores the challenges faced, specifically: students' perception of the difficulties and barriers in their future overseas study; and the expected support refers to the facilitation and assistance they deem necessary for their successful learning in the foreign education context.

Stage 2 of the research includes three steps: the first is the validation of the appropriateness and coverage of the questionnaire for this research, using the Delphi technique and focus group triangulation. A Delphi test is usually used for evaluating viewpoints and generating consensus through two or more rounds of information iteration, and it is particularly suitable for the situation where it is difficult to convene the research participants physically together (Somerville, 2008; Yousuf, 2007; Stitt-Gohdes and Crews, 2004; Ziglio, 1996), as was the case in this research. Focus groups of experts are used to obtain consensual viewpoints or insights on certain issues (Evason and Whittington, 1997). 
The second step was a pilot test, by real world respondents, of the developed questionnaire and refinement before data collection; the final version of questionnaire is in the Appendix. To increase the accuracy of data collection, the questions were listed in both English and Chinese, which have been validated through a translation and back translation process.

The third step, survey data collection was carried out in two rounds (the second round is for test-retest to examine the reliability) in the two institutions, as well as an examination of validity and reliability.

Stage 3 contains two steps: the first is data analysis by applying ANOVA and T-test/Z-test on the collected data; the authors also designed a protocol (Figures 1 and 2) for in-depth statistics analysis of ordered categorical type data. The second step involves the summary of findings and consequential conclusions, implications, limitation and future research proposals.

\section{Validation of the appropriateness and coverage of the questionnaire and reliability of the survey investigation}

\section{Validity}

To ensure a thorough understanding by the respondents, the questions were provided in both English and Chinese. The questions were originally developed in English, then following the steps of validating translated questionnaires (Sangster, et al., 1994), they were translated into Chinese by a bilingual researcher, and then translated back to English by another bilingual researcher. Afterwards, a group of four bilingual academics worked together to examine the two versions to ensure the consistency and accuracy in the questions' meaning.

The majority of the data for this survey are unordered categorical (nominal) type (Mplus, 2014) and it is very important to validate the appropriateness and coverage of the questionnaire content for fulfilling the purpose of the research. After the wording of the questionnaire has been assessed for its accuracy and consistency between the English and Chinese versions, they were sent to twelve potential Chinese international students who functioned as a Delphi test panel for further examination.

The Delphi technique used here is simplified slightly by using a five-point rating scale to assess the questions, and the standard for acceptable 'consensual agreement' ( 5 very appropriate/very sufficient coverage; 4 appropriate/sufficient coverage; 3 unsure; 2 inappropriate/insufficient coverage; 1 very inappropriate/very insufficient coverage). The 12 Chinese students (six from private and six from public institutes) were required to rate the proposed questions on their appropriateness and coverage to the research focus/purpose, and propose their own points if they see any critical information missing.

Because there were not many disagreements among the panel and only two further viewpoints from the Delphi group experts were added to the original questionnaire, after two iterations, the Delphi group reached its final consensual assessment, and each individual panel member's ratings on the questions were above 4 . 
After the Delphi group confirmation, the previous translation and back translation process has been repeated to ensure the confirmed version's language consistency.

To further triangulate the question contents' suitability for the research purpose, another focus-group session of experienced academics has been conducted to screen the questions, the six focus group participants are higher education business or management programme educators who have been working in the field for more than five years and have been teaching both domestic and international students including Chinese ones. The focus group has assessed each of the questions with regard to their appropriateness to the research and their coverage of the research field; following the same five-point scale, the focus group experts' ratings with average scores of 4.17 to 4.67 (appropriateness) and 4.5 to 4.83 (coverage) have confirmed the developed questionnaire's applicability and effectiveness in seeking the research findings.

The survey sample group consisted of 403 students from the business and management programmes in one top private institute (CUUA, 2014b) and 207 students from one top public institute (CUUA, 2014a). The students from these two institutions are among those possessing high-level capability and academic knowledge in their respective sectors in China. In the questionnaire, respondents were given space to add new points they deemed necessary, however none of them from either of the institutes' sample groups has proposed additional points in the feedback; this situation further evidenced the coverage and appropriateness of the research questions.

The participants of the research are all mature adults who participated voluntarily; they were fully informed of the research purpose, assured of confidentiality and were free to withdraw from participation at any time. All the participants had gone through all their participating stages of the research.

\section{Reliability}

To assess reliability, the test-retest technique (Farahat et al., 2003; Sapountzi-Krepia et al., 2009; Marx et al., 2003) has been applied. The two rounds of data collection using the same questionnaire in the two institutes were carried out between three days to one week (Hendrickson et al., 1993; Marx et al., 2003). Based on the collected data, the calculated p values are listed in Table 2, they demonstrate that the findings from the research can be relied on for drawing conclusions.

Table 2. Reliability test scores (two tail Z-test score at $95 \%$ confidence level)

\begin{tabular}{|l|l|l|l|l|l|l|l|l|}
\hline $\begin{array}{l}\text { Question No. } \\
\text { Institute type }\end{array}$ & $\mathrm{R} 1$ & $\mathrm{R} 2$ & $\mathrm{R} 3-1$ & $\mathrm{R} 3-2$ & $\mathrm{R} 4$ & $\mathrm{R} 5$ & $\mathrm{R}$ & $\mathrm{R} 7$ \\
\hline Public & 0.21 & 0.56 & 0.87 & 0.65 & 0.78 & 0.96 & 0.91 & 0.96 \\
\hline Private & 0.53 & 0.72 & 0.87 & 0.76 & 0.92 & 0.96 & 0.80 & 0.96 \\
\hline \\
Institute type & $\mathrm{R} 8$ & $\mathrm{R} 9$ & $\mathrm{C} \& \mathrm{~S} 1$ & $\mathrm{C} \& \mathrm{~S} 2$ & $\mathrm{C} \& \mathrm{~S} 3$ & $\mathrm{C} \& \mathrm{~S} 4$ & $\mathrm{C} \& \mathrm{~S} 5$ & \\
\hline Public & 0.94 & 0.86 & 0.75 & 0.77 & 0.82 & 0.17 & 0.44 \\
\hline Private & 0.42 & 0.69 & 0.88 & 0.68 & 0.91 & 0.95 & 0.79 \\
\hline
\end{tabular}




\section{Research conduct and findings}

Based on the feedback from pilot testing (four students from the private and five from the public institute), a minor refinement on the questionnaire layout has been conducted (no unclear questions as confirmed by the pilot test), then the research data collection was carried out in the two institutes.

To ensure the effectiveness of data collection, at both institutes the authors made contacts with the potential respondents in the business and management programmes beforehand, to explain the purpose of the research and encourage their participation. This was a time-consuming but, research wise, a very effective process, which increased the number of actual respondents. Then the survey questionnaires were distributed to the students in these programmes in the two institutes. In the private institute the effective feedback rate is 33.6\% (159 completed questionnaires), and in the public institute $32.9 \%$ (68 completed questionnaires), these feedback rates are satisfactory compared to some other survey researches' as low as $10 \%$ feedback rate (Baruch \& Holtom, 2008). Table 3 summarises the profile of the survey respondents. All the students who filled in the questionnaires agreed to participate in the second round of retest for reliability, and more than $98 \%$ of them in both institutes have fully completed and returned the questionnaires within one week in the retest round.

Table 3. General profile of the survey respondents from the two institutes

\begin{tabular}{|c|c|c|c|c|c|c|c|c|}
\hline Programme & $\begin{array}{l}\text { Institute } \\
\text { type }\end{array}$ & Percentage & $\begin{array}{l}\text { Year of } \\
\text { study }\end{array}$ & $\begin{array}{l}\text { Institute } \\
\text { type }\end{array}$ & Percentage & Gender & $\begin{array}{l}\text { Institute } \\
\text { type }\end{array}$ & Percentage \\
\hline \multirow{2}{*}{$\begin{array}{l}\text { Logistics } \\
\text { management }\end{array}$} & Public & 8.82 & \multirow{2}{*}{ Year 1} & Public & 1.47 & \multirow{4}{*}{ Female } & \multirow{2}{*}{ Public } & \multirow{2}{*}{25.00} \\
\hline & Private & 15.58 & & Private & 20.10 & & & \\
\hline \multirow{2}{*}{$\begin{array}{l}\text { Business } \\
\text { administration }\end{array}$} & Public & 42.65 & \multirow{2}{*}{ Year 2} & Public & 52.94 & & \multirow{2}{*}{ Private } & \multirow{2}{*}{57.29} \\
\hline & Private & 46.23 & & Private & 49.75 & & & \\
\hline \multirow{2}{*}{$\begin{array}{l}\text { Financial } \\
\text { management }\end{array}$} & Public & 39.71 & \multirow{2}{*}{ Year 3} & Public & 32.35 & \multirow{4}{*}{ Male } & \multirow{2}{*}{ Public } & \multirow{2}{*}{75.00} \\
\hline & Private & 32.66 & & Private & 30.15 & & & \\
\hline \multirow{2}{*}{ Others } & Public & 8.82 & \multirow{2}{*}{ Year 4} & Public & 13.24 & & \multirow{2}{*}{ Private } & \multirow{2}{*}{42.71} \\
\hline & Private & 5.53 & & Private & -- & & & \\
\hline
\end{tabular}

From Table 3, one can see that, the vast majority of the respondents are from three main business and management programmes: business administration, financial management and logistics management, which correspond to the current preference of the Chinese international students' mostly selected study programmes (EOL, 2013a,b; Huashen-Edu, 2012; EOL, 2014). 
Among the respondents, there are a few exceptions scattered on a few other programmes but they have no clear concentration and as they are not the prioritised overseas programmes by the potential Chinese international students, they are excluded from the analysis at below.

\section{Difference analysis among programmes, gender and year of study within and between the sample groups of the two institutes}

The answers to the enquiry of 'Willingness for abroad study', 'The financial sources for abroad study', 'Likeability on English among all the subjects' and 'Academic performance on English learning' are ordered categorical type data, to find the similarity and difference within and between private and public institutes' sample groups, the analysis on these data follows the procedures illustrated by Figures 1 and 2, in respect to the three dimensions of programme, gender and year of study. For the rest of the answers to other survey questions, they are unordered categorical (nominal) type data, descriptive statistical analysis is applied.

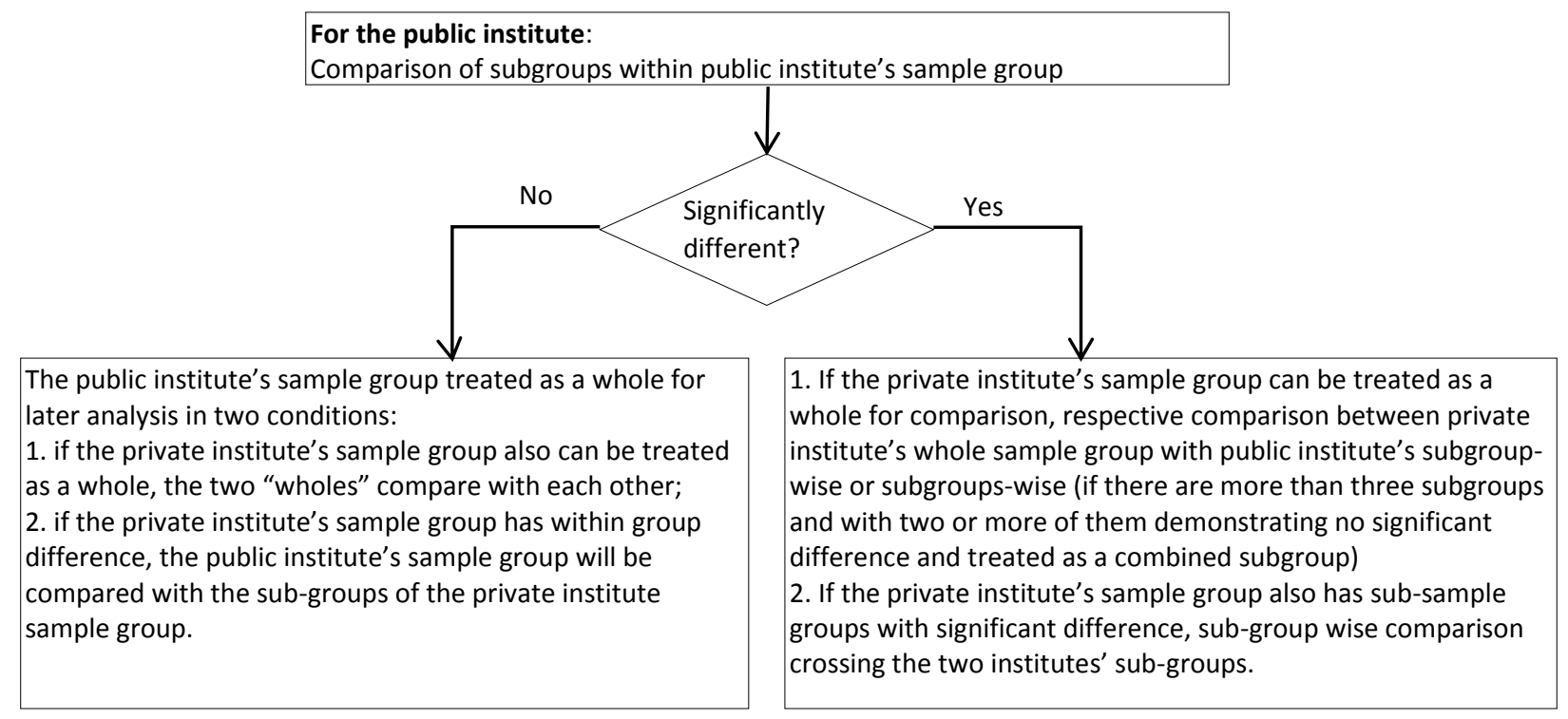

Figure 1. Data analysis protocol from the aspect of the public institute

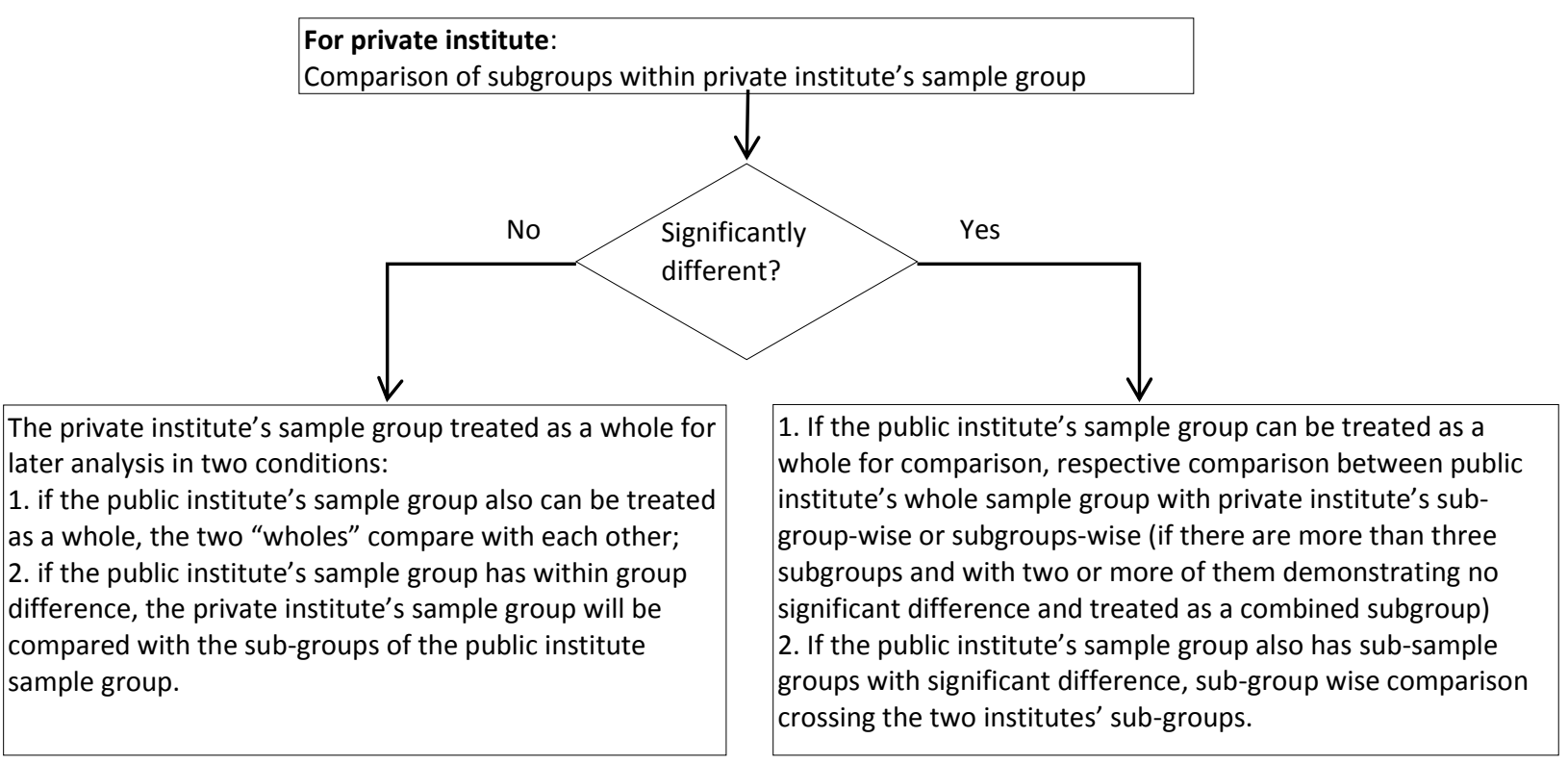


Figure 2. Data analysis protocol from the aspect of private institute

\section{The readiness of the students for overseas study}

In this paper, the readiness of the students for overseas study is reflected by three aspects: (1) willingness to go abroad; (2) the sources of finance; (3) the skills or competence for fulfilling the study tasks. Within these aspects the data for 'Willingness for abroad study', 'The financial sources for abroad study', 'Likeability on English among all the subjects' and 'Academic performance on English learning' are tested at 95\% confidence level.

\section{The willingness for overseas study}

Within each institute

ANOVA and Z-test/T-tests found no significant difference in the willingness for study abroad, with regard to the respective sub-sample groups of different gender, year of study and programmes from samples in the private institute. The same situation applies to the public institute. Thus for 'willingness for overseas study', the sample groups from both the public and private institutes can be treated as two 'wholes' in the analysis.

Within the private institute, $3.9 \%$ of the respondents have confirmed their willingness to go abroad to study in the UK or other ESDC higher education institutions, while within the public institute $25 \%$ have such a confirmation. The percentage of the graduates in the sample as a whole intending to study abroad is smaller than from other research (Huashen-Edu, 2012). Whether this difference is due to this research just focusing on business and management programmes, which are not representative for graduates as a whole, or there still exist other reasons remain a future research topic.

Between the sample groups of the public and private institutes

There are more public institute's students willing to go abroad for further higher education than their private institute's peers (Z-test, $\mathrm{p}=0.003$ ); the underlying reason for this phenomenon is also an interesting topic that deserves future investigation.

\section{The sources of the finance to the students' overseas study}

Within the sample groups of the public and private institutes

For the students in the private institute, there is no significant difference by programme $(\mathrm{p}=0.2$ to 0.6 ), with the majority (78.9\%) of the students relying on family funding, which is a stable and continuous finance source; only $4 \%$ of students anticipate their overseas study will be supported by their own work, and the rest of the students (17.1\%) believe their overseas study will be financed by a combination of family funding and their own work.

Female students $(85.1 \%)$ tend to rely more on family support than their male peers $(70.59 \%)$ $(\mathrm{p}=0.01)$. Among female students, 3.5\% said they will rely on self-work to support their study, while $4.71 \%$ of males indicated this option; for the combination of family funding and self-work as finance source, $11.4 \%$ female students and $24.71 \%$ male students chose this option. 
Year 2 students indicated a much higher level of reliance on family funding (90.9\%) than Year 1 $(62.5 \%)$ and Year $3(52.4 \%)$ students (for Year 2 to Year $1 \mathrm{p}=0.02$; Year 2 to Year $3 \mathrm{p}=0.001$ ). Meanwhile, Year 1 and Year 3 students did not differ significantly $(\mathrm{p}=0.32)$. Financing through self-work was a very low level preference by all (Year 1, 5\%; Year 2, 1\%; Year 3, 5.1\%). Financing through a combination of family support and own work was higher: $32.5 \%$ Year 1 students, $8.18 \%$ Year 2 students and $42.5 \%$ Year 3 students selected this option.

For the students in the public institute: there was no significant difference in sub-groups based on programmes, gender and year of study (ANOVA p values ranging from 0.19 to 0.91 ). Thus, for this question, the public institute's sample can be treated as a whole. Among them, $67.4 \%$ will be relying on family financial support, only $4.7 \%$ will be self-financing, and $27.9 \%$ will be relying on a combined finance sources of self and family support.

\section{Sample groups between public and private institutes}

From the previous section, one can see that the private institution's students demonstrated more diversified situations, thus except programme-wise, they need to be compared as sub-groups in gender and year of study with the whole sample group of the public institute.

By programme, the students from the public institute and private institute as two 'wholes' demonstrated significant difference $(\mathrm{p}=0.04)$. The sample group of private institute showed a higher level $(78.9 \%)$ of relying on financial support from their family than their public institute peers $(67.4 \%)$.

There is a significant difference between the private institution's female group and the public institution's whole sample ( $\mathrm{p}=0.006$ ), with $85.1 \%$ of the private institute's female students sample group relying on family finance, compared to the public sample group's $67.4 \%$. The private institute's male students group showed no significant difference with the public institute's students $(\mathrm{p}=0.34)$.

The private institute's Year 1, 2 and 3 sub-groups, compared with the public institute's sample group as a whole, demonstrated no significant difference for Year $1(\mathrm{p}=0.96)$ and Year $3(\mathrm{p}=$ $0.29)$ but for Year $2(\mathrm{p}=0.001)$ the private institute sub-group showed a significant difference from their public peers; $90.9 \%$ of Year 2 private institution students will be relying on their family financial support for their study abroad. This demonstrated the inconsistency of the private institute students' financing plan for study abroad.

\section{Equipment and possession of the competence and skills}

The competence and skills for overseas study refer to competence in English and the mastery of the relevant subject knowledge. Competence in English is examined by three questions in the survey: the first one enquiring if English is the mostly favourite subject for students, the second one enquiring if English is the best performing subject of students, the third one enquiring if the students have passed IETLS/TOEFL tests. 


\section{Students' likeability of English language}

Within sample groups respectively

For students in the private institute, respondents on different programmes and different years of study did not demonstrate significant difference with regard to their likeability of English language (ANOVA $\mathrm{p}=0.37$ and $\mathrm{p}=0.06$ respectively). There is significant difference between male and female students $(\mathrm{p}=0.01)$, with female students demonstrating a higher level favouring English language. Thus, the private institute's sample group needs to have a further gender comparison separately with the public institute sample.

For the public institute there are no significant difference between programme, gender and year-of-study sub-groups (ANOVA $\mathrm{p}=0.32,0.42$ and 0.63 respectively). Thus the public institute's sample group can be treated as a whole for analysis.

\section{Between sample groups}

The two institutes' sample groups demonstrated significant difference on likeability of English language $(\mathrm{p}=0.001)$, the private institute's students have a higher level favouring English language among other subjects, compared to their public institute's peers. The private institute's male and female students both demonstrated a higher level of favouring English than their peers in the public institute ( $\mathrm{p}=0.003$ and 0.007 respectively).

\section{Students' performance level on English subject}

\section{Within sample groups respectively}

Students in both the private and public institutes did not demonstrate any significant difference on their performance levels in English $(\mathrm{p}=0.23,0.69$ and 0.61 respectively for programme, gender and Year of study in the private institute; $\mathrm{p}=0.95,0.75$ and 0.4 respectively for the public institute). Thus they can both be treated as a whole for further analysis.

\section{Between the two institutes' sample groups}

The students from both the private and public institutes have no significant difference, namely they are performing at the same level on English language learning $(\mathrm{p}=0.32)$.

As a summary, $15.1 \%$ of the private institute sample group and $17.7 \%$ of the public institute sample group students claim that English is the subject receiving the highest mark among all; while $23.1 \%$ private institute sample students and $17.7 \%$ public institute sample students claim that English is the subject receiving the lowest mark among all.

Thus, one can argue that from the aspect of English language, not many students have demonstrated a high level of English subject performance among their academic subjects. A majority of the students only have the vocabulary from subject text books (Table 4), which are not sufficient for studying and living in an English-speaking country. This situation has been evidenced by the difficulties encountered by the international students in their studying after commencing the host institutions' programmes (Bamford, 2008; Hellstén and Prescott, 2004; Wong, 2004).

\section{Rest of the elements for readiness}

For the rest of the questions, their answers are unordered categorical (nominal) type data, thus the two sample groups will be treated as two wholes for descriptive analysis. The analysis in this 
way can provide sufficient insights for fulfilling the exploratory purpose of this research. The answers to these questions from the sample groups in both of the two institutes are listed in Table 4.

Table 4. Summary of the answers to the rest of the questions (elements)

\begin{tabular}{|c|c|c|}
\hline Elements & $\begin{array}{l}\text { Answers from private institute sample } \\
\text { group }\end{array}$ & $\begin{array}{l}\text { Answers from public institute sample } \\
\text { group }\end{array}$ \\
\hline $\begin{array}{l}\text { English language tests having } \\
\text { been passed }\end{array}$ & $\begin{array}{l}\text { Having passed IETLS exam }(5.3 \%) \\
\text { Having passed TOEFL exam }(7.9 \%) \text {. }\end{array}$ & $\begin{array}{l}\text { Having passed IETLS exam }(5.8 \%) \\
\text { Having passed TOEFL exam }(5.8 \%) \text {. }\end{array}$ \\
\hline $\begin{array}{l}\text { The most difficult aspect in } \\
\text { English learning }\end{array}$ & $\begin{array}{l}\text { Comprehension }(19.6 \%) \text {; Speaking } \\
(23.6 \%) \text {; Reading }(8.5 \%) \text {; Writing } \\
(16.1 \%) \text {; All }(30.2 \%) \text {. }\end{array}$ & $\begin{array}{l}\text { Comprehension (22.06\%); Speaking } \\
(36.76 \%) \text {; Reading }(5.88 \%) \text {; Writing } \\
(11.76 \%) \text {; All }(23.53 \%) \text {. }\end{array}$ \\
\hline $\begin{array}{l}\text { The best way for learning } \\
\text { English }\end{array}$ & $\begin{array}{l}\text { Reciting words/texts }(21.6 \%) \text {; More } \\
\text { practicing of speaking at English salon } \\
(31.2 \%) \text {; Attending dual language } \\
\text { courses }(9.6 \%) \text {; Watch English film/TV } \\
\text { and Read English magazines }(15.1 \%) \text {; } \\
\text { English extensive training course } \\
(15.1 \%) \text {. }\end{array}$ & $\begin{array}{l}\text { Reciting words/texts }(14.71 \%) \text {; More } \\
\text { practicing of speaking at English salon } \\
(36.76 \%) \text {; Attending dual language } \\
\text { courses }(10.29 \%) \text {; Watch English } \\
\text { film/TV and Read English magazines } \\
(22.06 \%) \text {; English extensive training } \\
\text { course }(13.24 \%) \text {. }\end{array}$ \\
\hline $\begin{array}{l}\text { The level of mastering subject } \\
\text { English words }\end{array}$ & $\begin{array}{l}\text { Only those from subject text books } \\
(52.3 \%) \text {; Words from business dictionary } \\
(12.1 \%) \text {; Words for BEC test }(5.5 \%) \text {; } \\
\text { Words from the dual-language courses } \\
(12.1 \%) \text {. }\end{array}$ & $\begin{array}{l}\text { Only those from subject text books } \\
(66.18 \%) \text {; Words from business } \\
\text { dictionary }(10.29 \%) \text {; Words for BEC } \\
\text { test }(4.41 \%) \text {; Words from the } \\
\text { dual-language courses }(16.18 \%) \text {. }\end{array}$ \\
\hline $\begin{array}{l}\text { Reasons for joining the } \\
\text { programme (not directly } \\
\text { relevant to the competence/skills, } \\
\text { but a reflection of students' } \\
\text { willingness for learning the } \\
\text { subject knowledge) }\end{array}$ & $\begin{array}{l}\text { Self-preference }(40.7 \%) \text {; Suggestions } \\
\text { from family/friends }(32.2 \%) \text {; } \\
\text { Introduction from newspapers/ } \\
\text { magazines }(2.5 \%) \text {; Promising career } \\
\text { prospect }(12.1 \%) \text {. }\end{array}$ & $\begin{array}{l}\text { Self-preference }(50 \%) \text {; Suggestions } \\
\text { from family/friends }(22.06 \%) \text {; } \\
\text { Introduction from newspapers/ } \\
\text { magazines }(7.35 \%) \text {; Promising career } \\
\text { prospect }(17.65 \%) \text {. }\end{array}$ \\
\hline $\begin{array}{l}\text { The level of mastering subject } \\
\text { Knowledge }\end{array}$ & $\begin{array}{l}\text { Can master all the knowledge points } \\
\text { following the course outline }(41.3 \%) \text {; Just } \\
\text { passing the exam/ assignment }(31.2 \%) \text {; } \\
\text { Can apply the learnt knowledge into } \\
\text { practice }(22.2 \%) \text {; Not sure }(5.29 \%) \text {. }\end{array}$ & $\begin{array}{l}\text { Can master all the knowledge points } \\
\text { following the course outline ( } 75 \%) \text {; Just } \\
\text { passing the exam/ assignment }(11.8 \%) \text {; } \\
\text { Can apply the learnt knowledge into } \\
\text { practice }(13.2 \%) \text {; Not sure }(0.00 \%) \text {. }\end{array}$ \\
\hline
\end{tabular}

The findings reveal that vast majority of the students neither like English most nor have best performance in English among their academic subjects nor passed the IETLS/TOEFL tests, which are international standard tests of English competence as entrance criteria for the vast majority of ESDC higher education institutions. Overall, the majority of the students are not very competent in English language proficiency and thus are not fully ready for overseas study. The majority of the private institute students and some public institute students also need further improvement in subject knowledge to ensure their readiness to cope with the academic challenges in overseas institutes. 


\section{Anticipated challenges from the students for their overseas study and their expected support from the host institutions or staff}

The questions enquiring about the challenges for students' overseas study and expected support require nominal type data answers, respondents can provide multiple answers to the questions, thus descriptive statistical analysis has been applied. The summarised answers to the relevant questions corresponding to these issues are listed in Table 5.

Table 5. Answers to questions (elements) enquiring anticipated challenges and expected support for overseas study

\begin{tabular}{|c|c|c|}
\hline Element & $\begin{array}{l}\text { Answers from private institute sample } \\
\text { group }\end{array}$ & $\begin{array}{l}\text { Answers from public institute sample } \\
\text { group }\end{array}$ \\
\hline $\begin{array}{l}\text { The biggest barriers } \\
\text { for overseas study }\end{array}$ & $\begin{array}{l}\text { Language }(42.7 \%) \text {; Cultural difference } \\
(23.1 \%) \text {; Life style }(25.1 \%) \text {. }\end{array}$ & $\begin{array}{l}\text { Language (45.59\%); Cultural difference } \\
(39.71 \%) \text {; Life style }(14.71 \%) \text {. }\end{array}$ \\
\hline $\begin{array}{l}\text { The deemed } \\
\text { advantage of the } \\
\text { teaching strategy of } \\
\text { overseas institutes }\end{array}$ & $\begin{array}{l}\text { Teamwork spirit build-up ( } 24.6 \%) \text {; } \\
\text { Independent learning capability } \\
\text { enhancement }(45.7 \%) \text {; Peer student } \\
\text { communication enhancement }(19.6 \%) \text {. }\end{array}$ & $\begin{array}{l}\text { Teamwork spirit build-up ( } 14.71 \%) \text {; } \\
\text { Independent learning capability } \\
\text { enhancement }(58.82 \%) \text {; Peer student } \\
\text { communication enhancement }(26.47 \%) \text {. }\end{array}$ \\
\hline $\begin{array}{l}\text { The most expected } \\
\text { from the staff in the } \\
\text { overseas institutes }\end{array}$ & $\begin{array}{l}\text { Fully understanding the English } \\
\text { competence level of the international } \\
\text { students }(28.6 \%) \text {; More introduction of } \\
\text { the local culture (19.6\%); Encouraging/ } \\
\text { facilitating students participating/talking } \\
\text { in class discussion ( } 22.1 \%) \text {; Often } \\
\text { introducing the cultural difference } \\
\text { between countries ( } 7 \%) \text {; Applying } \\
\text { different methods in class delivery } \\
(12.6 \%) \text {; Directly reminding students of } \\
\text { cultural taboo }(2.5 \%) \text {. }\end{array}$ & $\begin{array}{l}\text { Fully understanding the English } \\
\text { competence level of the international } \\
\text { students ( } 19.12 \%) \text {; More introduction of } \\
\text { the local culture (14.71\%); Encouraging/ } \\
\text { facilitating students participating/talking } \\
\text { in class discussion ( } 35.29 \%) \text {; Often } \\
\text { introducing the cultural difference } \\
\text { between countries ( } 8.82 \%) \text {; Applying } \\
\text { different methods in class delivery } \\
(17.65 \%) \text {; Directly reminding students of } \\
\text { cultural taboo }(1.47 \%) \text {. }\end{array}$ \\
\hline $\begin{array}{l}\text { The reasons for not } \\
\text { willing to talk in the } \\
\text { class in overseas } \\
\text { study }\end{array}$ & $\begin{array}{l}\text { Having language difficulty }(51.5 \%) ; \\
\text { Being afraid of saying opinion wrongly } \\
(16.4 \%) \text {; Not willing to give opinion } \\
\text { publicly }(15.2 \%) \text {; Not fully mastering } \\
\text { subject knowledge }(7.9 \%) ; \text { Lack of } \\
\text { confidence }(9.1 \%) .\end{array}$ & $\begin{array}{l}\text { Having language difficulty }(42.4 \%) \text {; } \\
\text { Being afraid of saying opinion wrongly } \\
(25.4 \%) \text {; Not willing to give opinion } \\
\text { publicly }(15.3 \%) \text {; Not fully mastering } \\
\text { subject knowledge ( } 10.29 \%) \text {; Lack of } \\
\text { confidence }(11.9 \%) \text {. }\end{array}$ \\
\hline $\begin{array}{l}\text { The anticipated } \\
\text { biggest difficulties at } \\
\text { the beginning stage of } \\
\text { overseas study }\end{array}$ & $\begin{array}{l}\text { Lack of personal capability }(32.7 \%) \text {; Not } \\
\text { good at communication }(26.6 \%) \text {; High } \\
\text { level of mental pressure }(8.5 \%) \text {; Not used } \\
\text { to the class teaching strategy }(10.1 \%) \text {; } \\
\text { Cannot follow the delivery pace in the } \\
\text { class }(4 \%) \text {; Lack of self-control capability } \\
\text { to form good learning habit }(3.5 \%) \text {. }\end{array}$ & $\begin{array}{l}\text { Lack of personal capability }(17.65 \%) \text {; } \\
\text { Not good at communication }(16.18 \%) \text {; } \\
\text { High level of mental pressure }(29.41 \%) \text {; } \\
\text { Not used to the class teaching strategy } \\
(10.29 \%) \text {; Cannot follow the delivery } \\
\text { pace in the class }(20.59 \%) \text {; Lack of } \\
\text { self-control capability to form good } \\
\text { learning habit }(4.41 \%) \text {. }\end{array}$ \\
\hline
\end{tabular}


Based on the feedback (Table 5), one can argue that for the students from both the private and public institutes, the anticipated barriers or difficulties affecting international students' overseas learning mainly include: language competence; cultural difference; communication skills; students' classroom engagement; students' subject knowledge level; students' ability to adjust quickly to the new learning and teaching environment; students' ability to cope with pressure; students' confidence and self-control capability; students' ability to learn new knowledge continuously. Of course, apart from language competence, subject knowledge and cultural difference awareness (to a lesser extent) these are issues that all students have to learn to cope with. Among these barriers or difficulties, the most salient issue is the capability in English language. For the private institute's students, the mastery of subject knowledge is another more salient challenge for their overseas study, compared to their public institute peers; this situation is a reflection of the general academic characteristics of the students in Chinese private institutes (Yu, 2011; Chen, 2011; Ye, 2008; Jin and Yin, 2009; Mao, 2008).

The respondents have also expressed their expected support from the host institutions and staff, including: understanding and appreciation of the international students' English level and competence; more introduction of the local culture to the students; encouragement and facilitation of students to engage in class discussion; introduction of the cultural difference between countries to increase the students' cultural awareness; application of different class delivery methods to enhance students' learning efficacy; reminding students of local cultural taboos for appropriate behaviour and communication.

\section{Concluding remarks}

The empirical findings from this research, focusing on business and management programmes, reveal the potential Chinese students' readiness for study abroad and their anticipated challenges during their overseas study as well as the expected support.

The respondents of this research are current students in one top public institute and one top private institute in China. In general, there are more students from the public institute planning to pursue further higher education abroad.

The majority of the sample of Chinese students are financially ready for overseas study through relying on their family funding, which is, currently, a very stable and prevalent financing source for study abroad (Huashen-Edu, 2012). Meanwhile female students in the private institute demonstrate higher-level reliance on family financing. This might be a reflection of the general attitude of students towards their overseas study financing plan and the family financial conditions of the student groups from the two types of institutes. The situation suggests that the ESDC higher education institutions, in developing their recruitment advertisements, focus not only on the potential international students who are currently their main targets but also on their parents who can function as the finance sources to enable overseas study. Another way to promote recruitment might be through the provision of facilitation from the host institutions on finding a part-time job, which can be an incentive for enrolment to those international students wishing to finance their study by self-support or a combination of family and self-support. Of 
course, this should comply with the national law or regulation and produce no negative impact on students' academic learning.

The research also reveals that the majority of the sample of potential international students from both types of institute are not fully ready with regard to their English language competence, evidenced inter alia by the low pass rate of IETLS/ TOEFL tests.

When it comes to subject knowledge, students from the public institute have a higher level of readiness for overseas study than the private institute students, as more than $70 \%$ of the sample claim mastery of all the required knowledge points, which is much higher than their counterparts in the private institute.

For the students with low levels of subject knowledge, they need to improve themselves before going abroad; meanwhile the overseas institutes, besides providing pre-sessions on English, also need to provide sessions on subject knowledge, especially for the students from Chinese private institutes, to enhance the international students' knowledge pool and capability before they commence the formal programme together with their local peers in the host institutions. English language pre-session is an often-seen provision in the UK and other ESDC higher education institutions; however, subject knowledge pre-sessions, which are rarely available, should be an initiative receiving more emphases from the higher education institutions' management and staff; and should be allocated more resources.

The investigation has also identified, from the potential Chinese students' viewpoints (Tables 4 and 5), the challenges for overseas study and what the overseas host institutions and staff should do to facilitate and help in their learning process. They emphasise the institutes' and staff's facilitation of students' awareness and proper adjustment to the local culture, the staff's careful design of teaching delivery to ensure an effective learning process, the staff's encouragement and facilitation of students' class discussion and confidence in communication, most importantly the staff should understand that the international students in general do not have an English language skill comparable to their native peers, at least at the initial stage; among these points, the staff's appreciation of students' language level and the encouragement and facilitation of class engagement, are the things mainly expected by the potential international students.

The sample students also highlighted the main advantages of overseas study: teamwork spirit building; independent learning capability enhancement; and communication skills enhancement. The perception also reflects the key virtues emphasised by international students to be obtained through overseas study besides academic knowledge. Correspondingly, the host institutions and staff need to do more in these areas to enhance the students' learning experience.

However, education is fundamentally a mutual process of teaching and learning, thus to ensure a thorough learning experience, international students should also actively communicate with their tutors and the host institutions about any issue they are facing and seek support from them. Besides providing learning and living support to international students after they have joined the programmes, host institutions should also clearly communicate to international students the available support well in advance of their departure for the overseas study. Perhaps even go 
further and include detailed information on learning and living support for international students in their recruitment brochures, which will help institutions attract more international students.

\section{Implications}

The findings from this investigation is informative for the higher education institutions in the ESDCs (such as UK) in deciding their recruitment criteria and marketing approaches for international students and the development of strategies and practices in teaching and facilitating international students for their learning and living in an environment new to them.

The insights obtained from both private and public Chinese institutes' students before departure for their overseas study also contribute to the knowledge pool of internationalisation of higher education provision in ESDCs, in view of the Chinese students' readiness and the anticipated challenges for overseas study as well as expected support from the host institutions and staff.

The research highlighted the importance of provision of subject knowledge pre-sessions for the Chinese international students, particularly those from private institutes, to ensure their fruitful and successful engagement with programmes in the host institutions, together with their local peers.

With regard to the Chinese international students' English competence, in the initial semester, the ESDC higher education institutions might need to allocate extra time for their examinations or assignments, or focus more on their learning rather than the wording when marking the student work.

Meanwhile, the research findings can also guide the Chinese institutes cooperating with ESDC higher education institutions to prepare their students before departure to the foreign host institutions.

\section{Limitation}

Although very informative for the teaching and learning and marketing strategies' and action plans' development for higher education institutions recruiting or intending to recruit Chinese international students, the findings of the research were from the respondents in one private and one public institutes. Thus, the universal applicability of the findings is limited. However, as an exploratory investigation, the insights obtained are effective in guiding the relevant decision-makings of the host institutions.

\section{Future research}

Based on the current findings, the following future research could be conducted:

- A wider range investigation to include more institutes in both private and public sectors and at different table ranks, to obtain more insights.

- An investigation in the ESDCs' higher education institutions, to study the current strategies and practices the institutions are implementing in facilitating their international students' learning process and their readiness for their courses. 
- A larger-scale comparative investigation of the difference between Chinese public and private institute students' capability, performance and preference for overseas study and the underlying reasons as well as performance improvement measurements.

- An investigation on the preference, anticipation and expectation on overseas study from the potential international students' parents, to inform the development of host institutions' recruitment advertisements for a more inclusively targeted marketing.

- Extending the research focus to include programmes from other disciplines, to examine holistically the current percentage of overall Chinese graduates willingly to go abroad for overseas higher education.

\section{References}

Bamford, J. (2008), Strategies for the Improvement of International Students' Academic and Cultural Experiences of Studying in the UK, The Enhancing Series of Case Studies: Internationalisation Learning Experience, Hospitality, Leisure, Sport and Tourism Network. November, The Higher Education Academy.

Baruch, Y. and Holtom, B. C. (2008), Survey response rate levels and trends in organizational research, Human Relations, 61 (8), pp. 1139-1160.

Beijing Foreign Studies University (BFSU) (2011), the prospect analysis of the career future for business administration programmes. Available at: http://www.beiwaionline.com/aboutbeiwai/ wljyztc/webinfo/1321337126826829.htm. Accessed 15 August 2013.

Bodycott, P. and Lai, A. (2012), The Influence and Implications of Chinese Culture in the Decision to Undertake Cross-Border Higher Education, Journal of Studies in International Education, 16 (3), pp. 252-270.

Chen, W. (2011), How to Get Out of the Low-level Dilemma for Private Colleges and Universities in China - A Perspective of Funding Structure, Educational Research, 7 (378), pp. 43-46. In Chinese.

China University Alumni Association (CUUA) (2014a), Top 100 Chinese universities named in 2014, Shanghai Jiaotong University top 3. Available at: http://www.cuaa.net/cur/2014/. Accessed 10 April 2014.

China University Alumni Association (CUUA) (2014b), Top 100 Chinese private universities named in 2014, Hunan International Economics University top 1. Available at: http://www.cuaa.net/cur/2014/09.shtml. Accessed 11 April 2014.

Ministry of Education of the People's Republic of China (DOE) (2012), The statistics of the overseas study in 201. Available at: http://www.moe.gov.cn/publicfiles/business/ htmlfiles/moe/s5987/201202/130328.html. Accessed 15 March, 2014

Evason, E. and Whittington, D. (1997), 'Patients' perceptions of quality in a Northern Ireland Hospital trust: a focus group study', International Journal of Health Care Quality Assurance, 10 (1), pp. 7-19.

China Education Online (EOL) (2013a), The report on the trend of overseas study in 2013. Available at: http://www.eol.cn/html/lx/baogao2013/page1.shtml. Accessed 16 April 2014. China Education Online (EOL) (2014), The report on the trend of overseas study in 2014. Available at: http://www.eol.cn/html//x/2014baogao/content.html. Accessed 19 April 2014.

China Education Online (EOL) (2013b), Listing the hottest 10 programmes in business and management study for higher education. Available at: http://www.eol.cn/html/g/pdgkzy/ glxzy.shtml. Accessed 16 April 2014. 
Farahat, F. M., Rohlman, D. S., Storzbach, D., Ammerman, T. and Anger, W. K. (2003), Measures of Short-Term Test-Retest Reliability of Computerized Neurobehavioral Tests, Neurotoxicology, 24, pp. 513-521.

Higher Education Academy (HEA) (2010), Teaching International Students. Available at: http://www.adm.heacademy.ac.uk/news/sector-news/teaching-international-students/. Accessed 15 May 2014.

Higher Education Academy (HEA) (2013), Apply for a Teaching Development Grant Thematic areas - Internationalisation. Available at: http://www.heacademy.ac.uk/tdg/grants. Accessed 16 April 2014.

Hellstén, M. and Prescott, A. (2004), Learning at University: The International Student Experience, International Education Journal, 5 (3), pp. 344-350.

Hendrickson, A. R., Massey, P. D. and Cronan, T. P. (1993), On the Test-Retest Reliability of Perceived Usefulness and Perceived Ease of Use Scale, MIS Quarterly, June, pp. 227-230.

HESA (2007), Press release 108 - HESA Students in HEIs 2005/06 reveals, India Now Number 2 Provider of Overseas Students to UK, Higher Education Statistics Agency.

HESA (2012), Press release 172 - Non-UK domicile students, Higher Education Statistics Agency.

Hou, J., Montgomery, C. and McDowell, L. (2014), Exploring the diverse motivations of transnational higher education in China: complexities and contradictions, Journal of Education for Teaching, 40 (3), pp. 300-318.

Huashen-Edu (2012), Investigation on the thought of Chinese students for overseas study in 2012. Available at: http://www.huashen- edu.com/article_10008358.html. Accessed 26 April, 2014.

Huazhong University of Science \& Technology (HUST) (2010), Wave on, ready for sailing - the employability of management programmes. Available at: http://job.hust.edu.cn/show/article. htm?id= 6541.16. Accessed April, 2014.

Jackson, D. and Chapman, E. (2012), Non-technical competencies in undergraduate business degree programs: Australian and UK perspectives, Studies in Higher Education, 37 (5), pp. 541-567.

Jin, Z. and Yin, H. (2009), The Current Problems, the Causes and the Countermeasures of the Development of China's Private Universities, Private Education Research, 7 (46), pp.19-22, In Chinese.

Luke, A. (2011), Generalizing Across Borders: Policy and the Limits of Educational Science, Educational Researcher, 40 (8), pp. 367-377.

Mao, Y. (2008), Analysis on the Equity between the Chinese Public and Private Higher Education Institutes, Education Learning, 8. Available at: http://www.jxedu.gov.cn/ zwgk/xbjyky/\%20xbjkgh/2010/10/2010100310222481.html. Accessed 21 April 2014. In Chinese.

Marginson, S. (2006), Dynamics of national and global competition in higher education, Higher Education, 52, pp. 1-39.

Marx, R. G., Menezes, A., Horovitz, L., Jones, E. C. and Warren, R. F. (2003), A comparison of two time intervals for test-retest reliability of health status instruments, Journal of Clinical Epidemiology, 56, pp. 730-735.

Montgomery, C. (2010), Understanding the International Student Experience: Universities into the $21^{\text {st }}$ Century, NewYork, N.Y.: Palgrave Macmillan. 
Mplus (2014), Chapter 5: Confirmatory Factor Analysis and Structural Equation Modelling. Available at: https://www.statmodel.com/usersguide/chapter5.shtml. Accessed 22 April 2014. Peking University (2014), Available at: http://english.pku.edu.cn/Admission/International Students/. Accessed 16 May 2014.

Qiang, Z. (2003), Internationalization of Higher Education: towards a conceptual framework, Policy Futures in Education, 1 (2), pp. 248-270.

Qide-Education (2013), Qide-Education Report of Chinese Graduates' Overseas Study Intention investigation in 2013. Available at: http://edu.sina.com.cn/a/2013-01-15/ 1632224517.shtml. Accessed 23 April 2014

Sangster, R. L., Reynolds, R. W. and Tarnai, J. (1994), Translating a Telephone Survey on Alcohol and Drug Use: Processes and Lessons Learned, Abstract for 1994 AAPOR. Available at: www.bls.gov/ore/pdf/st940470.pdf. Accessed 26 April 2014.

Sapountzi-Krepia, D., Raftopoulos, V., Psychogiou, M., Tzavelas, G. and Vehvilainen-Julkunen, K. (2009), 'Test-retest reliability of the Kuopio instrument for fathers (KIF): a questionnaire to assess fathers' feelings, experiences and preparation for their wife/partner's delivery', Midwifery, 25, pp. 366-372.

Sawir, E. (2005), Language difficulties of international students in Australia: The effects of prior learning experience, International Education Journal, 6 (5), pp. 567-580.

Scott, P (ed) (1998), The globalization of higher education, Open University Press.

Stitt-Gohdes, W. L. and Crews, T. B. (2004), THE DELPHI TECHNIQUE: A RESEARCH STRATEGY FOR CAREER AND TECHNICAL EDUCATION, Journal of Career and Technical Education, 20 (2). Available at: http://scholar.lib.vt.edu/ejournals/JCTE/v20n2/. Accessed 16 August 2014.

Somerville, J. A. (2008), Effective Use of the Delphi Process in Research: Its Characteristics, Strengths and Limitations, Excerpt from Somerville, J. A. (2007). Critical factors affecting the meaningful assessment of student learning outcomes: A Delphi study of the opinions of community college personnel. Unpublished doctoral dissertation, Oregon State University, Corvallis, OR. Available at: http://jasomerville.com/wp-content/uploads/2011/08/Delphi Process080617b.pdf. Accessed 19 June 2014.

The Complete University Guide (2012), Percentage of International Students by Institution. Available at: http://www.thecompleteuniversityguide.co.uk/international/international-students -the-facts/by-university. Accessed November 28, 2012.

Tianjin Foreign Studies University (TFSU) (2014), Available at: http://www.tjfsu.edu.cn/ bindex/gjj1_gjjl.shtml. Accessed 19 May 2014.

UK Council for International Student Affairs (UKCISA) (2012), International students in UK higher education: key statistics, The UK Council for International Student Affairs. Available at: http://www.ukcisa.org.uk/about/statistics_he.php. Accessed 28 November 2012.

Wong, J. K.-K. (2004), Are the Learning Styles of Asian International Students Culturally or Contextually Based? International Education Journal, 4 (4), pp. 154-166.

Ye, W. (2008), The suggestions on establish internationally advanced and nationally top private higher education institute in our province. Available at: http://bj.crntt.com/crn-webapp/cbspub/ secDetail.jsp?bookid=34733\&secid=34851. Accessed 26 April 2014

Yemini, M. (2012), Internationalization assessment in schools: Theoretical contributions and practical implications, Journal of Research in International Education, 11 (2), pp. 152-164. 
Yu, L. (2011), On the development of China's private higher education sector in the internationalization era, Journal of Xi'an International University, 3, pp. 1-11. In Chinese.

Yousuf, M. I. (2007), Using Experts' Opinions Through Delphi Technique, Practical Assessment, Research \& Evaluation, 12 (4), pp.1-8. Available at: http://pareonline. net/getvn.asp?v=12\&n=4. Accessed 12 February 2014.

Ziglio, E. (1996), The Delphi method and its contribution to decision-making. In M. Adler and E. Ziglio (Eds.), Gazing into the oracle: The Delphi and its application to social policy and public health. London, England: Jessica Kingsley.

\section{Appendix. Questionnaire content}

\section{Readiness of subject knowledge and English language level:}

R1. Do you have the plan for abroad study?

1. Yes;

2. Unsure.

3. No.

R2. If you go abroad for further high education, your source of finance will be:

1. Support from family;

2. Self part-time job;

3. Support from family + Self part-time job;

4. Others

R3-1. English among all your subject courses, is:

1. The mostly favourable subject;

2. Unsure;

3. The least favourable subject;

Why?

R3-2. English among all your subject courses, is:

1.The best performing subject (received the highest mark) among all subjects;

2. Unsure;

3. The worst performing subject (received the lowest mark) among all subjects;

Why?

R4. Your English language level has reached:

1. Have passed IETLS exam;

2. Have passed TOEFL exam;

3. Others

R5. For applying English in your daily study and life, the most difficult aspect is:

1. Listening comprehension

2. Spoken English; 
3. Reading

4. Writing

5. All of the aforementioned aspects

R6. According to your opinion, the best way to learn English should be:

1. Recite English words;

2. Frequently go to English corner or salon for more often English usage in communication;

3. Attending due language courses;

4. Watch English spoken TV programmes/movies or read English magazines;

5. Participate English training classes;

6. Others

R7. Your mastering level of English vocabulary:

1. The words on the subject textbooks;

2. Vocabulary in business dictionary;

3. Vocabulary for Business English Certificates (BEC) examination;

4. Words in the due language courses;

5. Others

R8. The reason for your choice of your programme is:

1. Self preference;

2. Family recommendation;

3. Reports from the mediums like newspapers, magazines, etc.;

4. The career prospect is regarded as bright for the graduates from such a programme;

5. Others

R9. How do you evaluate your own mastering level of your subject knowledge?

1. Can master the learning of all the knowledge points required by the course descriptor;

2. Just have passed the final exam;

3. Can apply the learnt subject knowledge into practice;

4. Have published papers pertaining to the learning subject;

5. Others

Your anticipated barriers for abroad study and your expected support and facilitation:

C\&S 1. According to your opinion, the biggest barrier for abroad study comes from:

1. Language;

2. Cultural background;

3. Local customs and life style;

4. Others

C\&S 2. According to your understanding, the main advantage for abroad study is:

1. Cultivate the capability of team work and cooperation;

2. Improve the independent learning capability; 
3. Enhance the communication between peer students

4. Others

C\&S 3. When you have arrived at your foreign host higher education institution, what will you mostly expect from the staff:

1. The staff should be fully aware and understand the overseas students' English level;

2. Provide more introduction about the local cultural background;

3. Actively encourage the students to express their own viewpoints in the class discussions;

4. Often introduce the cultural difference between countries;

5. Apply diversified teaching strategy in lectures' delivery;

6. Directly remind students of cultural taboos;

7. Others

$\mathrm{C} \& \mathrm{~S} 4$. In the foreign higher education institutions' classroom, the reason for your unwilling to speak out your viewpoints would be:

1. Restricted by the language communication capability;

2. Be afraid to speak something wrong and lose 'face' (to be laughed at or looked down upon by others);

3. Unwilling to express own opinion/viewpoints in public;

4. Do not have sufficient learning/grasp of subject knowledge;

5. Lack of self confidence;

6. Others

C\&S 5. According to your opinion, at the beginning stage of the abroad study, the biggest difficulty would be:

1. Self subject knowledge and capability are low;

2. Not good at communication with others;

3. Feel big psychological/mental pressure;

4. Not used to the class teaching strategy;

5. Can not follow the class learning/teaching pace;

6. Lack of capability of self control, difficult to form effective and efficient learning habit;

7. Others

C\&S 6. When you are abroad, what other support/facilitation do you still expect to get from the host institute/staff?

1 .

2

3.

4.

5.

6.

If you deem any other question(s) should be included in this questionnaire, please list them and your corresponding answers here. Thank you! 
1.

3.

4.

5.

6.

... 